\title{
The Social and Economic Impact of New Technology 1978-84: A Select Bibliography
}

Compiled by: Lesley Grayson, B.Sc.(Econ); A.L.A.

Co-published by: IFI/Plenum New York Washington London and

Technical Communications

100 High Avenue, Letchworth, Herts, SG6 3RR, England 


\section{国느}

British Library Cataloguing in Publication Data

\section{Grayson, Lesley}

The social and economic impact of new technology 1978-84.

1. Technology - Social aspects -

Bibliography

I. Title

016.3034'83 Z7914.S663

Distributed worldwide (except UK) by:

IFI/Plenum Data Company

A division of Plenum Publishing Company

233 Spring Street

New York, NY 10013

ISBN 978-1-4684-8260-7 ISBN 978-1-4684-8258-4 (eBook)

DOI 10.1007/978-1-4684-8258-4

(C) 1984 Technical Communications, UK

Softcover reprint of the hardcover 1st edition 1984

The work is protected by copyright. The rights covered by this are reserved, in particular those of translating, reprinting, radio broadcasting, reproduction by photo mechanical or similar means as well as the storage and evaluation in data processing installations even if only extracts are used. Should individual copies for commercial purposes be made with written consent of the publishers then a remittance shall be given to the publishers in accordance with $\$ 54$, para 2 , of the copyright law. The publishers will provide information on the amount of this remittance. 


\section{Lesley Grayson, B.Sc.(Econ); A.L.A.}

Lesley Grayson qualified in Economics at London University and studied for her post-graduate Diploma in Librarianship at Ealing School of Librarianship. She joined the staff of the Greater London Council Research Library in 1973 and moved to the British Library Research and Development Department in 1976 to carry out investigative research into local government information. The publication resulting from her research 'Library and Information Services for Local Government in Great Britain' remains the definitive work on the subject.

Lesley Grayson now runs her own company 'Environmental Abstracts Services' in Chandlers Ford, Hampshire, UK.

\section{Technical Communications}

Technical Communications publishes specialist bibliographies providing detailed coverage of European and American literature (reports, books, articles, etc.), on specific interest areas. They are designed to be of practical use to professional engineers, researchers and managers by offering an overview of significant recent developments.

\section{Also available: \\ Energy Conservation in Buildings 1973-83: A Bibliography Wind Energy 1974-84: A Bibliography}




\section{Contents}

1. THE OVERALL PICTURE

1.1 General papers and books

1.2 Conferences, seminars and colloquia

1.3 Literature reviews and bibliographies

2. NATIONAL AND INTERNATIONALINITIATIVES, POLICIES AND POLITICAL MANIFESTOS

3. SOCIALIMPACTS

$\begin{array}{lll}3.1 & \text { Education and Training } & 13\end{array}$

3.2 Employment and Unemployment 16

$\begin{array}{ll}\text { 3.2.1 General issues } & 16\end{array}$

$\begin{array}{ll}3.2 .2 & 19\end{array}$

$\begin{array}{lr}\text { 3.2.2.1. National employment } & 19\end{array}$

3.2.2.2. Regional employment 22

3.2.3 Europe 23

3.2.4 Rest of the developed world 24

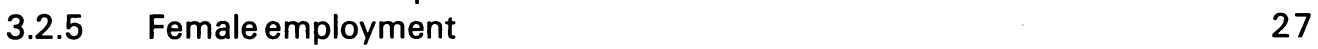

\begin{tabular}{ll}
3.3 & Data protection and security \\
\hline & 29
\end{tabular}

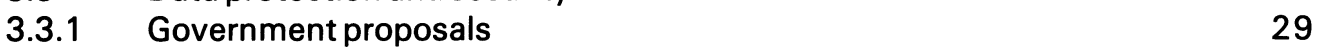

$\begin{array}{lll}3.3 .2 & \text { International reports } & 30\end{array}$

$\begin{array}{lll}\text { 3.3.3 Comment } & 31\end{array}$

$\begin{array}{lll}3.4 & \text { Working environment } & 34\end{array}$

3.4.1 Quality of working life 34

$\begin{array}{lll}3.4 .2 & \text { Health and safety } & 37\end{array}$

$\begin{array}{lll}3.4 .3 & \text { Homeworking } & 39\end{array}$

$\begin{array}{lll}3.5 & \text { Work and leisure } & 40\end{array}$

4. ECONOMIC STRUCTURE AND POLICY 43

4.1 National economy 43

$\begin{array}{lll}4.2 & \text { Regional economy } & 45\end{array}$

$\begin{array}{lll}4.3 & \text { Urban economy } & 46\end{array}$

4.4 Rural economy 47

$\begin{array}{lll}4.5 & \text { Science parks } & 47\end{array}$

5. IMPACT OF NEW TECHNOLOGY ON BUSINESS, INDUSTRY AND
COMMUNICATIONS

$\begin{array}{lll}5.1 & \text { Office automation } & 49\end{array}$

$\begin{array}{lll}5.2 & \\ 5.3 & \text { Industry and technology }\end{array}$

$\begin{array}{lll}5.3 & \text { Retailing } & 60\end{array}$

$\begin{array}{lll}5.4 & \text { Viewdata systems and cable television } & 61\end{array}$

$\begin{array}{lll}5.5 & \text { Public sector and business } & 65\end{array}$

6. ADMINISTRATIVE IMPACT AND INDUSTRIAL RELATIONS: IMPACT OF NEW TECHNOLOGY

$\begin{array}{lll}6.1 & \text { Management and new technology } & 69\end{array}$

6.1.1 General issues $\quad 69$

$\begin{array}{ll}\text { 6.1.2 Management skills } & 72\end{array}$

$\begin{array}{lll}\text { 6.1.3 Manpower planning and management } & 74\end{array}$

$\begin{array}{lll}6.2 & \text { Trade union reactions } & 76\end{array}$

$\begin{array}{ll}\text { 6.2.1 United Kingdom } & 76\end{array}$

$\begin{array}{lll}6.2 .2 & \text { Europe } & 79\end{array}$

$\begin{array}{lll}6.2 .3 & \text { Comment } & 79\end{array}$ 


\section{Introduction}

Silicon chip technology; microprocessor technology; information technology; or quite simply new technology. These are some of the names representing the microelectronics revolution depending upon the audience being addressed by speaker or writer. No previous new industrial development has caused such widespread publicity and discussion amongst users and researchers as the new technology. Concern is being expressed about the effects of new technology on employment, job satisfaction, social life, leisure activities and the economics of commerce and industry. The late 70s saw many doom-laden predictions of those effects but by 1983 both management and trade unions were taking a more objective view of the social and economic impacts, and many correspondents now see the new technology as a means of opening up new industries and overcoming the effects of world recessions.

The "chip" has involved the factory floor, the office, the supermarket and the home. Electronic funds transfer, electronic shopping, microelectronic domestic appliances, word processors and microprocessor-controlled machinery mean that the new technology has pervaded all aspects of social and economic life, and the developed countries are now coming to accept it as part of society as a whole.

Inevitably the flood of literature on the social and economic impacts of new technology has been overwhelming. Unfortunately the quality of information and arguments propagated at conferences, in journal papers and research reports has indicated that there has been little quantifiable evidence available on the effects of these impacts. However, in the last two years, serious studies have been undertaken at international, national and regional levels to investigate the real effects of the new technology and the eye-catching and misleading titles ("chips with everything") of the late 70s are rapidly becoming a thing of the past. It appears that the time has come to treat the "silicon chip" as an accepted part of society and therefore its effect on our lives is to be seriously researched.

This wideranging bibliography brings together American, British and European literature on the social and economic effects on government, industry, business and the home. It covers national policies, cable television, data protection, effects on employment (in particular women's employment) effects on quality of life at work and in leisure time, and the changes which need to be made in education and training policies to meet the challenge the new technology brings. Of particular importance is the inclusion of a section on management as so much depends on the competent and sympathetic manager where new technology is being introduced into working practices in the office or on the factory floor. The views of the trade union movement are also represented as well as a consideration of health and safety aspects of the new technology.

A bibliography of some 700 references cannot hope to be comprehensive, but by careful sifting through thousands of references, the author hopes to have captured a significant and representative collection which will enable the manager, the research worker, the trade union negotiator or the operator to understand both the benefits and the dangers the new technology brings to both the working environment and to social life.

The emphasis throughout has been on economic and social impacts of new technology, and therefore the technical aspects of microelectronics have been ignored. The references have also been restricted to those which are easily obtainable from academic, special or public libraries, or through national library services such as the British Library.

Some deliberate duplication of references has occurred where books, reports or papers cover two or more separate issues in some detail. Duplication rather than cross-referencing was felt to be more beneficial to the user of the bibliography in these instances. 